\title{
Correction: Expression of Hox genes during regeneration of nereid polychaete Alitta virens (Annelida, Lophotrochozoa)
}

\author{
Elena L Novikova ${ }^{*}$, Nadezhda I Bakalenko ${ }^{\dagger}$, Alexander Y Nesterenko and Milana A Kulakova
}

\begin{abstract}
After publication it was brought to our attention that there is an ambiguity in the title and in the abstract of our paper [1] that could lead to incorrect understanding of the name of the studied species. To avoid this, the correct title should read "Expression of Hox genes during regeneration of nereid polychaete Alitta virens (Annelida, Lophotrochozoa)" and the sentence "We have recently described the expression of 10 out of 11 Hox genes during postlarval growth of Alitta (Nereis) virens" in the abstract should read as "We have recently described the expression of 10 out of 11 Hox genes during postlarval growth of Alitta virens (formerly Nereis virens)."
\end{abstract}

Received: 25 June 2013 Accepted: 3 July 2013

Published: 6 August 2013

\section{Reference}

1. Novikova EL, et al: Expression of Hox genes during regeneration of nereid polychaete Alitta (Nereis) virens (Annelida, Lophotrochozoa). EvoDevo 2013, 4:14.

\section{doi:10.1186/2041-9139-4-21}

Cite this article as: Novikova et al:: Correction: Expression of Hox genes during regeneration of nereid polychaete Alitta virens (Annelida,

Lophotrochozoa). EvoDevo 2013 4:21.

\footnotetext{
* Correspondence: elena.novikova.03.06@gmail.com

${ }^{\dagger}$ Equal contributors

Saint-Petersburg State University, department of embryology, laboratory of experimental embryology, Petergof Oranienbaumskoe sh., 2, Saint

Petersburg, Russia
}

(c) 2013 Novikova et al.; licensee BioMed Central Ltd. This is an Open Access article distributed under the terms of the Creative Commons Attribution License (http://creativecommons.org/licenses/by/2.0), which permits unrestricted use, distribution, and reproduction in any medium, provided the original work is properly cited.
Submit your next manuscript to BioMed Central and take full advantage of:

- Convenient online submission

- Thorough peer review

- No space constraints or color figure charges

- Immediate publication on acceptance

- Inclusion in PubMed, CAS, Scopus and Google Scholar

- Research which is freely available for redistribution

Submit your manuscript at

www.biomedcentral.com/submit

\section{BioMed Central}

